\title{
THE EFFECT OF COMPENSATION, MOTIVATION, AND WORK SATISFACTION ON OJEK ONLINE DRIVER PERFORMANCE IN SURABAYA
}

\author{
Muhammad Kafid, \\ Faculty Of Economy And Business Narotama University Surabaya \\ muhkafiddd@gmail.com \\ Bayu Airlangga Putra \\ Faculty Of Economy And Business Narotama University Surabaya \\ bayuairlangga71@gmail.com
}

\begin{abstract}
The purpose of this study is to analyze the Influence of Compensation, Motivation, and Job Satisfaction on the Performance of Surabaya Regional Ojek Drivers Online. With a sample of 100 respondents. This research is quantitative and data collection through questionnaires and observations. Data analysis used is validity test, reliability test, classic assumption test, and multiple linear analysis test. The results showed that the Influence of the Effect of Compensation, Motivation, and Job Satisfaction on the Performance of Surabaya Regional Ojek Drivers on positive and significant results. The $f$ test results were known at 214,590> $f$ table 17,354 simultaneously. Partially compensation amounted to $.211 \mathrm{t}$ table 3,985 Significant effect on motivation of .119 t table of 2.689 has a significant effect on employee performance and job satisfaction of $.253 \mathrm{t}$ table 4.194 has a significant effect on employee performance.
\end{abstract}

Keywords: Compensation, Motivation, Satisfaction, Employee Performance.

\section{INTRODUCTION}

Go-Jek is an Indonesian transportation company that serves human and goods transportation through motorcycle taxi services. This company was founded in 2011 in Jakarta by NadiemMakarim. NadiemMakarim is known to have worked at a Mckinsey\& Company company a well-known consultant in Jakarta and spent three years working there. Also known that he once worked as a Co-Founder and Managing Editor at Zalora Indonesia and later became Chief Innovation officer of my card.Armed with a wealth of experience while working, NadiemMakarim then ventured to quit his job and founded the Go-Jek company in 2011. GOJEK activities are based on three core values: speed, innovation and social impact. GO-JEK drivers say that their income has increased since joining as a partner, they also get health and accident benefits, and get access to more customers through our application. GO-JEK has officially operated in 25 major cities in Indonesia, including Medan, Batam, Palembang, Pekanbaru, Jambi, Padang, Bandar Lampung, Greater Jakarta, Bandung, Sukabumi, Yogyakarta, Semarang, Solo, Surabaya, Gresik, Malang, Sidoarjo, Balikpapan ,Samarinda, Pontianak, Banjarmasin, Manado, Makassar, Denpasar, and Mataram. Go-Jek can be ordered through the Go-Jek App which can be downloaded via the Play Store or App store. In the first 1 month this application has reached 150 thousand downloads, with a rating of 4.4 out of 5 stars. The payment also has 2 ways, namely cash or using Go-Jek Credit (Go-Pay). Go- Jek Credit is a GO-Jek payment method that is made cashless and can be used to pay for all services. 


\section{Literature Review Compensation}

According to Mutiara S. Panggabean (2004: 75) Definition of Compensation According to Mutiara S. Panggabean Is Every Form of Award Provided by Employees as Servicefor Contributions They Give to Organizational

\section{Motivation}

ReturnsAccording to Djamarah (2002: 34) Defining Motivation as Energy Change In One Who Is Marked By The Appearance Of Feelling And Is Preceded By A Response To The Purpose. Changes in Energy in Someone That Are in the Form of a Real Activity in the Form of Physical Activity. Because Someone Has Specific Objectives And Activities, So A Person Has Strong Motivation To Achieve It With All The Efforts That He Can Do To Achieve Distribution.

\section{Job satisfaction}

According to SusiloMartoyo (1992: 115) Definition of job satisfaction according to SusiloMartoyo is one of the psychological aspects that reflect a person's feelings for his work, he will feel satisfied with the compatibility between abilities, skills and expectations with the work he faces.

\section{Employeeperformance}

Anwar PrabuMangkunegara (2009: 67) Performance is the result of work in quality and quantityachieved by an employee in carrying out his duties in accordance with the responsibilities given to him.

\section{Reliability and Validity Test Methods}

Definition of validity according to Azwar (1987: 173) is the extent to which the accuracy and accuracy of a measuring instrument (test) in performing its measuring function. A test is said to have high validity if the tool performs the measuring function appropriately or gives a measurement result that is appropriate for the purpose of the measurement.

Understanding reliability according to Sugiono (2005) a series of measurements or a series of measuring instruments that have consistency if the measurements made with the measuring instrument are carried out repeatedly. Test reliability, which is the level of consistency of a test, is the extent to which tests can be trusted to produce consistent scores, relatively unchanged even when tested in different situations.

\section{Multiple Regression Analysis}

This method is used to find out how much influence the independent variables (Organizational Culture, Policy, Job Satisfaction on Employee Performance dependent variables). Multiple linear regression models are used:

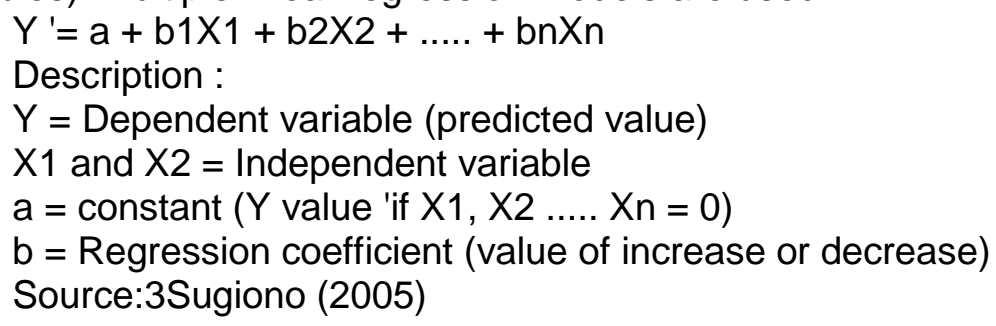




\section{Conceptual Framework}

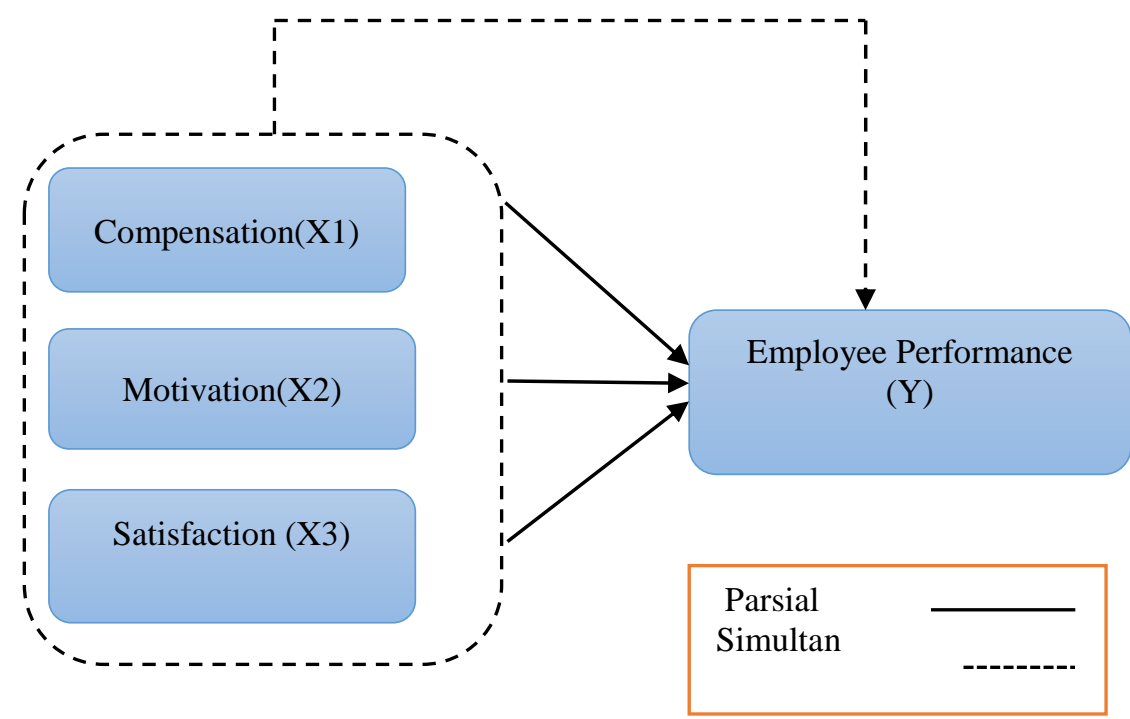

\section{Hypothesis}

Figure 1. Conceptual Framework

$\mathrm{H} 1$ : There is a partial compensation effect on the performance of online motorcycle taxi drivers in the Surabaya area.

$\mathrm{H} 2$ : There is a partial effect of motivation on the performance of online motorcycle taxi drivers in Surabaya.

H3: There is a partial effect of Job Satisfaction on the performance of Surabaya motorcycle taxi drivers.

$\mathrm{H} 4$ : There is an influence of compensation, motivation and job satisfaction simultaneously on the performance of Surabaya motorcycle taxi drivers.

\section{Types of}

\section{METHODOLOGY}

Research This study uses primary data. Primary data is the source of research data obtained3directly from the original source not through intermediary media

\section{Data Source}

Data will be obtained from the results of filling out questionnaires regarding compensation, motivationand job satisfaction on Employee Performance filled by online motorcycle taxi drivers in Surabaya

\section{Reliability and Validity}

\section{RESULTS AND DISCUSSION}

Based on research, the value of alpha cronbanch compensation is 0.801 , motivation is 0.735 , job satisfaction is 0.803 , and employee performance is 0.791 , which means that it is above the acceptance limit of 0.6 . Based on the research value of the correlation index for the relationship between the independent variables (compensation, motivation, and job satisfaction) and the dependent variable (employee performance) greater than 0.165 from the $r$ table and below the significant level of 0.05 , the results of validity tests of all items indicate positive result, therefore, the data is considered valid. 


\section{Results of Multiple LinearRegression}

Table 1. Multiple Linear Regression Analysis

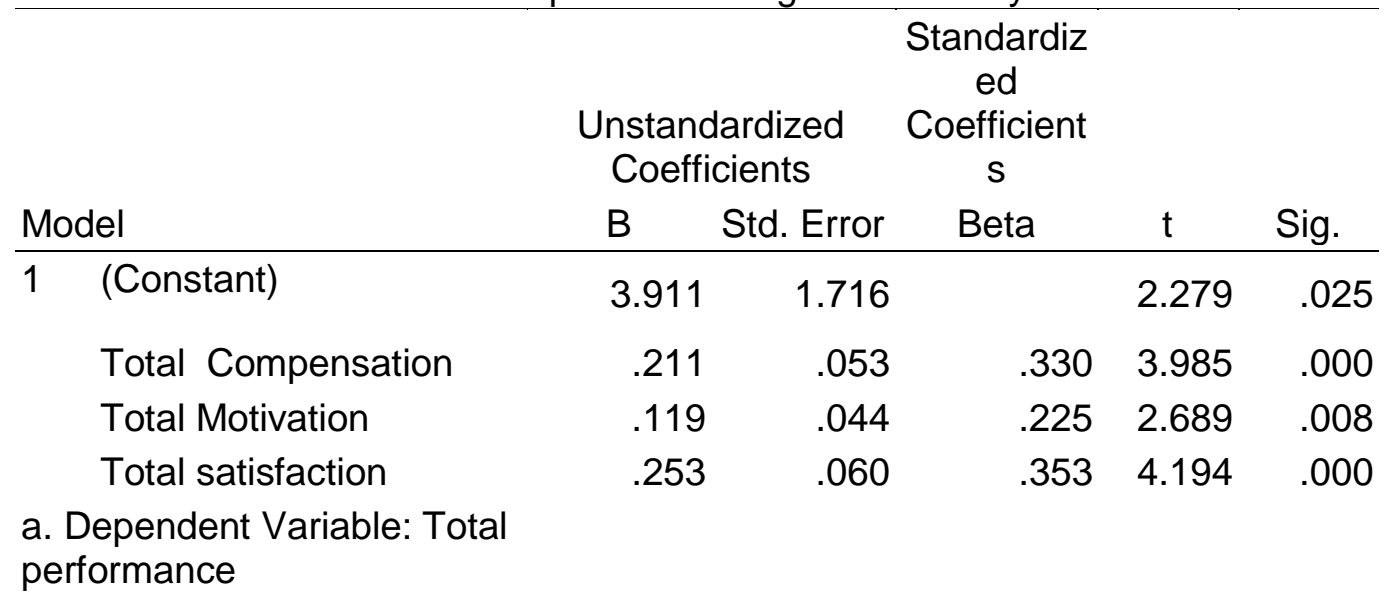

1. Retrieved constant $Y$ value of 3.911 means that the value of online motorcycle taxi driver performance Surabaya $(Y)$ equal to 3.911 unit if it is assumed that the compensation(X1), motivation (X2),job satisfaction (X3)then the performance of the Surabaya online motorcycle taxi driver $(Y)$ is 0 means that if the value of the independent variable 0 then the dependent or dependent variable will be 3.911 .

2. Value of compensation coefficient (X1) Compensation coefficient value (X1) of 0.211, if the performance of Surabaya online motorcycle taxi drivers increases compensation (X1) then it will increase the performance of Surabaya online motorcycle taxi drivers $(\mathrm{Y})$ by 0 , 0.211 units. Assuming the value of the other independent variables is zero.

3. The value of the motivation coefficient (X2) The value of the motivation coefficient (X2) is 0.119 , if the performance of Surabaya's online motorcycle taxi drivers increases motivation (X2) it will increase the performance ofmotorcycle taxi drivers

Surabaya(Y) equal to 0.119 units. Assuming the value of the other independent variables is zero.

4. Job satisfaction coefficient value (X3) Job satisfaction coefficient $(X 3)$ is 0.253 , if the performance of Surabaya motorcycle taxi drivers increases job satisfaction $(X 3)$ then it will increase the performance of Surabaya online motorcycle taxi drivers $(Y)$ by 0.253 units. Assuming the value of the other independent variables equal to zero.

\section{Results of R Square}

Calculation Results The coefficient of determination (R2)

Table 2. Result of $R$ Square

Summary

Model $^{\mathrm{b}}$

\begin{tabular}{llrrrr}
\hline \multicolumn{6}{c}{ Model Summary $^{\mathbf{b}}$} \\
\hline Model & R & R Square & $\begin{array}{c}\text { Adjusted R } \\
\text { Square }\end{array}$ & $\begin{array}{c}\text { Std. Error of } \\
\text { the Estimate }\end{array}$ & $\begin{array}{c}\text { Durbin- } \\
\text { Watson }\end{array}$ \\
\hline 1 & $.593^{\mathrm{a}}$ & .352 & .331 & 1.20388 & 1.537
\end{tabular}
a. Predictors: (Constant), Total satisfaction, Total compensation, Total motivavation.
b. Dependent Variable: Total performance

From the results of calculations using the SPSS version 18 program, it can be seen that the value of $R$ Square $=0.352$ shows the magnitude of the influence of compensation variable (X1), motivation (X2), and Job Satisfaction (X3), on Employee Performance (Y) is $35.2 \%$. It 
means that there are still influences of other variables of $64.8 \%$ that affect work performance but are not examined in this study.

\section{Classical Assumption}

Table 3. Classical Assumption

\begin{tabular}{|c|c|c|c|}
\hline \multicolumn{4}{|c|}{ Collinearity Statistics } \\
\hline Variabel & $\begin{array}{c}\text { Toleranc } \\
e\end{array}$ & VIF & Keterangan \\
\hline Compensaion $\left(\mathrm{X}_{1}\right)$ & 0,983 & 1,017 & Free multicoliarity \\
\hline Motivation $\left(X_{2}\right)$ & 0,965 & 1,037 & Free multicoliarity \\
\hline satisfaction $\left(X_{3}\right)$ & 0,952 & 1,050 & Free multicoliarity \\
\hline
\end{tabular}

Based on Table 4.18 it can be seen that the regression model is not experiencing multicollinearity disorders. This can be seen in thevaluetolerance of each independent variable greater than 0.1. The VIF calculation results also show that the VIF value of each independent variable is less than 10 . So it can be concluded that there is no multicollinearity between independent variables in the regrestheHeterocedasticity (Scatterplot and Glejser).

\section{Heteroskedacti}

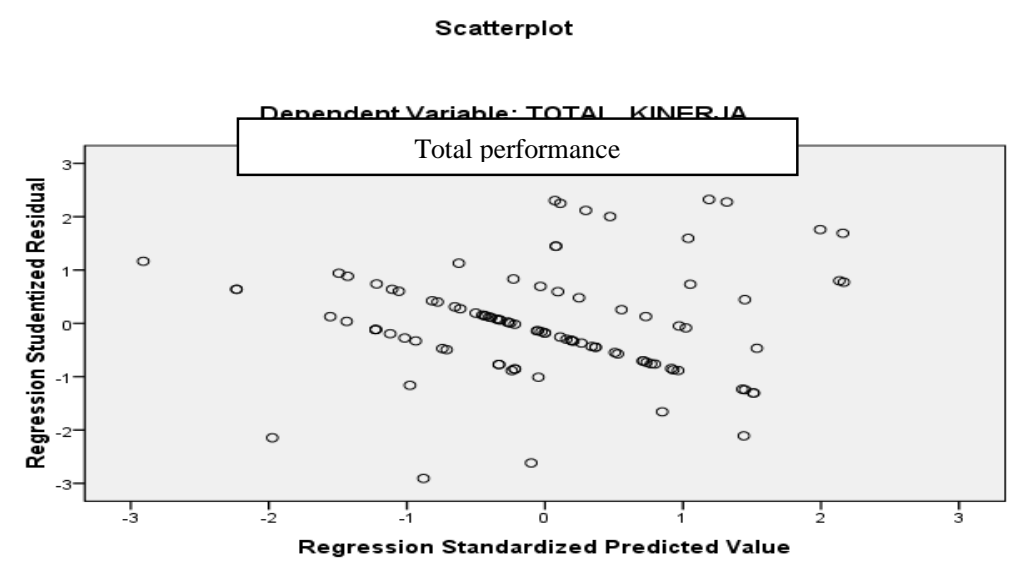

Figure 2. Heteroskedactivity Source:SPSS Output Data

Table 4.

\section{Coefficients $^{\mathrm{a}}$}

Model

1 (Constant)

Total compensation

Total motivation

Total satisfaction

a. Dependent Variable: absres

\section{Unstandardized Coefficients}

\section{B}

$-2,113$

Std. Error

, 075

,015

,030
,998

,038

,061

,054

\section{Standardized}

Coefficients

Beta

$\mathrm{t}$

$-2,118$

Sig.

, 037

,260

, 037

1,998

,253

$, 069 \quad, 559$
, 049

, 801

, 577

Based on heteroxide test results using glejser test, that the significant value (sig) for the compensation variable (X1) is 0.037 motivation (X2) motivation 0.049 and satisfaction 0.801 . Because the value of the three variables is greater than 0.05 , according to the basis of decision making in the glejser test, that is heteroxide free in the regression model. 


\section{Normality}

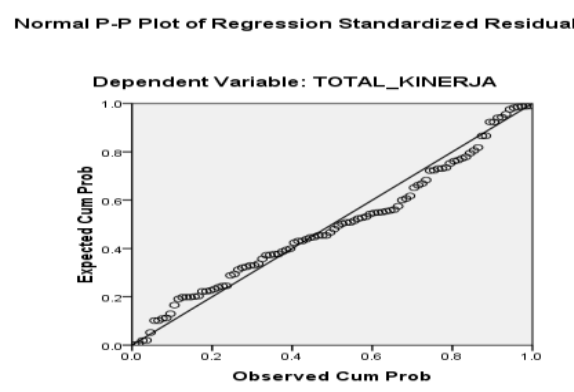

Figure 3. Data Normality

Based on the Above Graph Shows That All Existing Data Are Normal Distributions, Because All Data Spreads Forming Diagonal Straight Lines Such Data Meets Normal Assumptions Or Follow Normality Lines.

\section{F-Test}

Table 5.

F ANOVA Test Calculation Results ${ }^{b}$

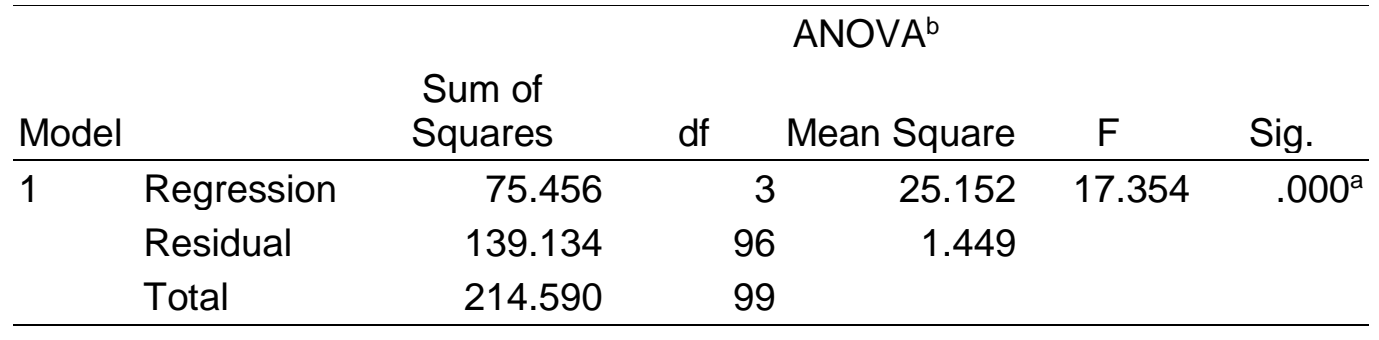

a. Predictors: (Constant), Total satisfaction,total motivation, Total compensation

b. Dependent Variable: total performance

$\mathrm{F}$ test calculation results obtained results $\mathrm{F}$ count 17,354 greater $\mathrm{F}$ Table 2.70 with a sign level of 0,000 smaller (a) 0.05 , because the probability is smaller 0.05 then $\mathrm{Ha}$ is accepted, meaning the variable reward, punishment and simultaneous communication with the performance of fashion division employees at PT. MitraAdi Perkasa Tbk Surabaya. Thus the fourth hypothesis "There is an influence of compensation, motivation and job satisfaction simultaneously on the performance of Surabaya online motorcycle taxi drivers" proved to be empirical truth. 


\section{T-Coefficients}

Table 6. T-Coefficients

\begin{tabular}{|c|c|c|c|c|c|c|}
\hline & & Coeffic & ients $^{a}$ & & & \\
\hline & & $\begin{array}{r}\text { Unstano } \\
\text { Coeffi }\end{array}$ & $\begin{array}{l}\text { lardized } \\
\text { cients }\end{array}$ & $\begin{array}{c}\text { Standardiz } \\
\text { ed } \\
\text { Coefficient } \\
\text { s }\end{array}$ & & \\
\hline & & $\mathrm{B}$ & Std. Error & Beta & $\mathrm{t}$ & Sig. \\
\hline 1 & (Constant) & 3.911 & 1.716 & & 2.279 & .025 \\
\hline & Total compensation & .211 & .053 & .330 & 3.985 & .000 \\
\hline & Total motivation & .119 & .044 & .225 & 2.689 & .008 \\
\hline & Total satisfaction & .253 & .060 & .353 & 4.194 & .000 \\
\hline
\end{tabular}

\section{CONCLUSSION}

Based on the analysis that has been carried out, the following conclusions can be drawn: 1. The results of this study are obtained from the SPSS calculation based on test, compensation variable has a significant effect on the performance of Surabaya online motorcycle taxi drivers where the value is significantly smaller than 0.05 which is 0,000 . This shows that the results of a hypothetical analysis which "partially compensates significantly has a significant effect on the performance of Surabaya motorcycle taxi drivers" are proven to be true. 2. The motivation variable has a significant effect partially on the performance of Surabaya online motorcycle taxi drivers where the value is significantly smaller than 0.05 , which is 0.008 . This shows that the results of the second hypothesis analysis "motivation partially has a significant effect on the performance of Surabaya motorcycle taxi drivers" proved the truth. 3 . Communication variables have a significant effect partially on the performance of Surabaya online motorcycle taxi drivers where significant values are smaller than 0.05 , which is 0,000 . This shows that the results of the third hypothesis analysis "communication partially has a significant effect on the performance of Surabaya motorcycle taxi drivers" proved to be true 4. The results of this study were obtained from SPSS calculations based on F test, Fcountobtained for motivation 17,354 and greater satisfaction fromFthetablesimultaneous2.70. effect It means that Ho is significantly rejected and towards $\mathrm{Hi}$ is accepted, to variable compensation performance, Surabaya online motorcycle taxi drivers $(Y)$. This shows that the third hypothesis which reads "compensation, motivation and job satisfaction simultaneously have a significant effect on the performance of Surabaya motorcycle taxi drivers" empirically proved the truth.

\section{Suggestions}

Suggestions that can be given include improving employee performance:1. The company must pay attention to compensation to prevent the injustice of Surabaya's online motorcycle taxi drivers in receiving compensation from the company ... 2. Future researchers are expected to enter and adding other variables as independent variables, so that further research that will be carried out will be able to find out other variables that greatly affect the performance of Surabaya motorcycle taxi drivers. This is important because from the results of the research that the authors did, it turns out that the independent variable studied 
consisting of compensation, motivation and job satisfaction was only able to predict $33.1 \%$ of the performance of Surabaya's online motorcycle taxi drivers.

\section{REFERENCES}

Arikunto.(2002). Data source. $\quad$ Retrieved from https://www.statistikian.com/2012/10/pengertian-data.html

Auliyana, E. (2017). Phenomenological Case Study of Wtp Audit Opinion among East Java Provincial Government Officials.Actual Accounting Journal, 4(1), 22-33. Retrieved from http://journal.um.ac.id/index.php/jaa Case Study of Mombasa Cement Limited, 5(3), 25-42. CASE STUDY: PDAM TIRTA SAKTI KABUPATEN KERINCI). COMPENSATION TOWARD JOB SATISFACTION IN, 3(3), 472-481.

Darma, PS, Supriyanto, US, Islam, U., Maulana, N., Ibrahim, M., \& Leadership, S. (2018) .THE EFFECT OF COMPENSATION ON SATISFACTION AND EMPLOYEES, (February). https://doi.org/10.18860/mec-j.v1i1.4524

Darwanto.(2014). Strategy for Strengthening Sharia Microfinance Based on Institutional Economics.NFERENCE,

Firmandari, N. (2014). Effect of Compensation on Employee Performance with Work Motivation as

Hidayati, N., Widyastutik, W., \&Wiliasih, R. (2016). The Factors Affecting the Amount of Islamic Microfinance and Its Impact on Customer's Turnover: KJKS BMT UGT Sidogiri Branch Koja Case Study Jakarta. Al-Muzara'ah Journal, 2(1), 49-68.

Influence, AND, Quality, T., \& Finance, L. (2013). FACTORS AFFECTING POSTEXPANSION AREA ASSET MANAGEMENT IN SOUTH TAPANULI DISTRICT RudiantoSimamora Alumni Master of Accounting Science at GadjahMada University Email: rasima_oke@yahoo.com Abdul Halim Faculty of Economics and Business GadjahMada University, 13(SEPTEMBER), 29-43.

Jean, KN, Ngui, TK, \& Robert, A. (2017). Effect of Compensation Strategies on Employee Performance: A job satisfaction as an intervening variable, 1(1), 37-48. Journal of Religious Social Research, 8(2), 501-522.

Kudus, UM (2018). The effect of compensation and motivation on the performance of civil servants with Leonardo, E., Business, PM, Management, PS, Petra, UK, \&Siwalankerto, J. (2015).THE EFFECT OF GIVING COMPENSATION TO EMPLOYEE PERFORMANCE IN PT. COPANITIA, 3(2), 3-6.

Lusri, L., Business, PM, Management, PS, Petra, UK, Siwalankerto, J., \& Work, KM (2017).THROUGH WORK SATISFACTION AS A MEDIATION VARIABLE IN EMPLOYEES PT. BORWITA CITRA PRIMA SURABAYA, 5(1).

manajemen.blogspot.com/2018/04/indikator-kinerja-karyawan.html

Meilani, D., \&Isd, M. (nd). DESIGN OF INVENTORY MANAGEMENT INFORMATION SYSTEM ( Moderating Variables (Study on Bank SyariahMandiri Yogyakarta Branch Office), IX(1), 25-34.

Nursalam.(2003). Sample. Retrieved from http://www.sumberpengertian.co/pengertianpopulasi-dan-sampel Pada, K., Trakindo, PT, \& Manado, U. (2015). THE INFLUENCE OF WORK DISCIPLINE, LEADERSHIP, AND MOTIVATION ON EMPLOYEE PERFORMANCE AT PT. MAIN TRAKINDO MANADO, 3(3), 352-361.

Robbins. (2016). Employee Performance Indicators. Retrieved from http: // skripsi- Rogo, N., Arifah, R., Andriani, F., Back, L., \&Taxavoidance, K. (2014).Interest analysis from, 1929.

Shahzadi, I. (2014). Impact of Employee Motivation on Employee Performance, 6(23), 159167. Sig, PT, Bitung, A., Sig, PT, \&Bitung, A. (nd). THE EFFECT OF MOTIVATION AND 
Yapari, S. (2016).THE EFFECT OF COMPENSATION AGAINST IN MALAKASARI TEKTONA BATU VILLAGE THE EFFECT OF COMPENSATION THROUGH EMPLOYEES 'PERFORMANCE AT BATU MALAKASARI TEKTONA VILLAGE WATERPARK, 2 